\title{
Effects of Nitrogen Limitation on Dunaliella sp.-Alteromonas sp. Interactions: From Mutualistic to Competitive Relationships
}

\author{
Myriam Le Chevanton, Matthieu Garnier *, Ewa Lukomska, Nathalie Schreiber, \\ Jean-Paul Cadoret, Bruno Saint-Jean and Gaël Bougaran
}

Laboratoire de Physiologie et de Biotechnologie des Algues, Institut Français de Recherche pour l'Exploitation de la Mer (IFREMER), Nantes, France

Interactions between photosynthetic and non-photosynthetic microorganisms play an essential role in natural aquatic environments and the contribution of bacteria and microalgae to the nitrogen cycle can lead to both competitive and mutualistic relationships. Nitrogen is considered to be, with phosphorus and iron, one of the main limiting nutrients for primary production in the oceans and its availability experiences

OPEN ACCESS

Edited by:

Xavier Mayali,

Lawrence Livermore National

Laboratory, USA

Reviewed by:

Dedmer Bareld Van De Waal, Netherlands Institute of Ecology, Netherlands

Sophie Rabouille,

Centre National de la Recherche

Scientifique, France

*Correspondence:

Matthieu Garnier

matthieu.garnier@ifremer.fr

Specialty section:

This article was submitted to

Aquatic Microbiology,

a section of the journal

Frontiers in Marine Science

Received: 12 January 2016 Accepted: 27 June 2016

Published: 08 July 2016

Citation:

Le Chevanton M, Garnier M, Lukomska E, Schreiber N,

Cadoret J-P, Saint-Jean B and Bougaran G (2016) Effects of Nitrogen

Limitation on Dunaliella sp.-Alteromonas sp. Interactions: From Mutualistic to Competitive Relationships. Front. Mar. Sci. 3:123.

doi: 10.3389/fmars.2016.00123 large temporal and geographical variations. For these reasons, it is important to understand how competitive and mutualistic interactions between photosynthetic and heterotrophic microorganisms are impacted by nitrogen limitation. In a previous study performed in batch cultures, the addition of a selected bacterial strain of Alteromonas sp. resulted in a final biomass increase in the green alga Dunaliella sp. as a result of higher nitrogen incorporation into the algal cells. The present work focuses on testing the potential of the same microalgae-bacteria association and nitrogen interactions in chemostats limited by nitrogen. Axenic and mixed cultures were compared at two dilution rates to evaluate the impact of nitrogen limitation on interactions. The addition of bacteria resulted in increased cell size in the microalgae, as well as decreased carbon incorporation, which was exacerbated by high nitrogen limitation. Biochemical analyses for the different components including microalgae, bacteria, non-living particulate matter, and dissolved organic matter, suggested that bacteria uptake carbon from carbon-rich particulate matter released by microalgae. Dissolved organic nitrogen released by microalgae was apparently not taken up by bacteria, which casts doubt on the remineralization of dissolved organic nitrogen by Alteromonas sp. in chemostats. Dunaliella sp. obtained ammonium-nitrogen more efficiently under lower nitrogen limitation. Overall, we revealed competition between microalgae and bacteria for ammonium when this was in continuous but limited supply. Competition for mineral nitrogen increased with nitrogen limitation. From our study we suggest that competitive or mutualistic relationships between microalgae and bacteria largely depend on the ecophysiological status of the two microorganisms. The outcome of microalgae-bacteria interactions in natural and artificial ecosystems largely depends on environmental factors. Our results indicate the need to improve understanding of the interaction/s between these microbial players.

Keywords: Dunaliella, Alteromonas, microalgae, bacteria, interactions, chemostat, nitrogen, DON 


\section{INTRODUCTION}

Phytoplankton primary production at the ocean surface contributes strongly to biochemical cycles of the Earth and especially to sequestration of atmospheric carbon dioxide (Falkowski et al., 1998). Nitrogen is considered to be the most limiting nutrient of oceanic productivity, especially in lowlatitude oceans, even though other nutrients such as phosphorus, iron, and vitamins can also co-limit oceanic productivity (Moore et al., 2013). Because the $\mathrm{N}$ cycle involves physical processes, biological activities of the different levels of the aquatic food chain, oceanic transport, and human activities, there are large temporal and geographical variations in the sources and fluxes of nitrogen in the oceans (Capone, 2000). It is acknowledged that nitrogen availability for primary production in marine systems is controlled by the $\mathrm{N}$ cycle and drives carbon sequestration by phytoplankton (Falkowski et al., 2008).

Autotrophic and heterotrophic microorganisms in photic zones live and interact within communities whose structure is mainly driven by trophic relationships (Strom, 2008). For example, heterotrophic bacteria can produce growth-promoting compounds for algae such as vitamins (Cole, 1982; Croft et al., 2005; Park et al., 2008) or can improve nutrient supply (Tai et al., 2009; Vasseur et al., 2012). Nitrogen and phosphorus are the main macro-elements required by phytoplankton. It is generally assumed that phytoplankton mainly uptake nitrogen in its mineral forms, including nitrate $\left(\mathrm{NO}_{3}^{-}\right)$, nitrite $\left(\mathrm{NO}_{2}^{-}\right)$, and ammonium $\left(\mathrm{NH}_{4}^{+}\right)$(Lipschultz, 1995), by a set of highaffinity transporters that compensate for the low concentration of these forms in the oceans (Charrier et al., 2015). On the other hand, several published works have made it clear that microalgae can also use organic forms of nitrogen via cellsurface and extracellular enzymatic processes (Palenik and Morel, 1990, 1991; Mulholland et al., 2002; Stoecker and Gustafson, 2003). The primary role of heterotrophic bacteria in the nitrogen cycle was presumed to be the release of inorganic nutrients during the decomposition of organic matter, thereby recycling nutrients to phytoplankton (Azam et al., 1983; Capblancq, 1990). In this picture, heterotrophic bacteria play the role of microbial decomposers helping primary productivity. However, more recent studies revealed a more complex picture, with bacteria using both inorganic and organic nitrogen and possibly even competing with microalgae for inorganic nitrogen (Kirchman, 1994; Kirchman and Wheeler, 1998; Zehr and Ward, 2002). Such competition for mineral nitrogen is, however, overlooked by most studies. One remaining issue is the impact of nitrogen limitation on the structure of planktonic communities driven by competitive and mutualistic interactions, especially on the abundance and activity of photosynthetic species.

Faced with the increasing potential of microalgae for diverse applications such as healthcare, cosmetics, food, animal feed, energy and phycoremediation (Spolaore et al., 2006; Barzegari et al., 2009; Mata et al., 2010; Park et al., 2010), there is growing interest in studies on bacteria-microalgae interactions for nutrient supply. Additionally, the cost of nitrogen for microalgal cultures is driven by fossil energy costs and can impair the economics of microalgae production. Therefore, such interaction studies are of particular interest for algae species cultivated on a large scale, such as microalgae of the genus Dunaliella (Hosseini Tafreshi and Shariati, 2009). Indeed, the maintenance of axenic cultures in large-scale production systems such as open ponds is unrealistic and most industrial cultures are therefore grown together with uncontrolled bacterial populations that may either improve or impair microalgae growth (see Natrah et al., 2014 for a review).

The present paper addresses the impact of nitrogen limitation on the interactions between heterotrophic bacteria and phytoplankton species. We studied the influence of the bacterium Alteromonas sp. on the physiology of the microalga Dunaliella sp. and on nitrogen repartition between the different fractions. In an earlier study, we had found that the addition of the bacteria Alteromonas sp. to batch cultures of Dunaliella sp. resulted in higher final biomass and nitrogen incorporation in microalgae (Le Chevanton et al., 2013). We suggested that the underlying mechanisms could be related to a better use of nitrogen, resulting from bacterial remineralization of dissolved organic nitrogen released by the algae. Benefits for Dunaliella sp. growth in mixed culture with Alteromonas sp. were observed in batch mode when nitrogen was tapering off and producing a final starvation effect, but it remained to be seen how such a mixed system would behave under a continuous but limiting supply of nitrogen and how culture conditions could affect the outcome of the interactions. Indeed, several previous studies (Currie and Kalff, 1984; Bratbak and Thingstad, 1985; Mindl et al., 2005) on microalgae-bacteria interactions in continuous culture under phosphorus-limited conditions revealed competitive relationships for phosphorus. In the present study, we therefore focused on testing mixed Dunaliella sp.-Alteromonas sp. cultures in terms of growth and nitrogen incorporation in ammonium-limited chemostat. Replicated mixed cultures were thus compared to axenic cultures at two different dilution rates. Carbon and nitrogen were monitored in microalgal and bacterial populations and in non-living particulate matter. Dissolved organic and inorganic nitrogen were monitored in the medium. This made it possible to assess the influence of Alteromonas sp. on biomass and nitrogen incorporation by Dunaliella sp. cultivated in chemostat for the two dilution rates and to compare our results with those previously obtained in batch culture (Le Chevanton et al., 2013).

\section{MATERIALS AND METHODS}

\section{Mixed and Axenic Strains}

The axenic culture of Dunaliella sp. strain SAG19.3 and the mixed Dunaliella sp.-Alteromonas sp. SY007 culture were set up as previously described in Le Chevanton et al. (2013). Both strains were maintained at $20^{\circ} \mathrm{C}$ under continuous light with daylight fluorescent tubes (100 $\mu$ molphotons.m $\left.\mathrm{m}^{-} 2 . \mathrm{s}^{-1}\right)$ on artificial seawater (ASW, salinity 35) enriched with modified Walne's medium (Walne, 1970), with ammonium used as the nitrogen source instead of nitrate.

\section{Experimental Design for Axenic Cultures in Chemostat}

Starter cultures of axenic and mixed strains were grown by batch. Cells were harvested by centrifugation, suspended in ASW then 
transferred into the $5 \mathrm{~L}$ flasks at $0.1 \times 10^{6} \mathrm{C} / \mathrm{ml}$ with modified Walne's medium. Bubbling with $0.22 \mu \mathrm{m}$ filtered air (Midisart, Sartorius) allowed the homogenization of cultures and slightly positive pressure to protect against biological contamination. Temperature was set at $20^{\circ} \mathrm{C}$ and irradiance at $250 \mu \mathrm{mol}$ photons. $\mathrm{m}^{-2} \cdot \mathrm{s}^{-1}$ with six fluorescent tubes (Osram, 54W965). $\mathrm{pH}$ was regulated at 7.7 with a PID controller device by automatic $\mathrm{CO}_{2}$ supply. Chemostats were maintained by the continuous input of modified Walne's medium with $250 \mu \mathrm{M}$ ammonium to ensure nitrogen limitation. The $\mathrm{N}: \mathrm{P}$ ratio of medium is $=1$.

Axenic Dunaliella sp. and the Dunaliella sp.-Alteromonas sp. mixture were cultured in duplicate for 85 days in chemostat where they were subjected to two successive dilution rates (D): low dilution rate at $0.05 \mathrm{~d}^{-1}$ from day 1 to 35 and high dilution rate at $0.3 \mathrm{~d}^{-1}$, from day 35 to 79 . These $\mathrm{D}$ correspond to conditions that allow 15 and $90 \%$ of the experimental maximal growth rate of Dunaliella sp. SAG19.3, measured in a previous study (Le Chevanton et al., 2013). D was checked daily by weighing the output of the system (see Supplementary Material). At day 80 , a batch phase was started by stopping the pumps and adding $150 \mu \mathrm{M}$ ammonium in order to ensure that the cultures are limited by nitrogen.

\section{Analyses \\ Populations}

Bacterial and algae populations were monitored daily during the entire duration of the experiment. Dunaliella sp. cell density and cell size were measured using a cell counter (HIAC, Hach Ultra, USA). Cell biovolume was computed from mean cell diameter by assuming spherical shape. Bacterial concentration was estimated by cytometric analysis (BD Accuri Cytometer, USA) after fixation with $2 \%$ formaldehyde and SYBR-green staining (Lonza, Switzerland). Microscopic observations were made weekly on an Olympus BH2-RFCA microscope equipped with an Olympus light source for excitation. Images were acquired using a CCD camera (Qimaging RETIGA 2000R). At the end of the experiment, bacteria from the mixed culture were isolated on Marine Agar (BD Difco ${ }^{\mathrm{TM}_{2}} 2125$ USA, 10 days of incubation at $20^{\circ} \mathrm{C}$ ) and characterized by random amplification of polymorphic DNA (RAPD) to verify the absence of contamination. Extraction PCR and RAPD reactions were performed as described in Le Chevanton et al. (2013).

\section{Particulate Organic Carbon and Nitrogen}

Culture samples were filtered daily on precombusted $25 \mathrm{~mm}$ GF/D (2.7 $\mu \mathrm{m}$, Whatman) and GF/F (0.7 $\mu \mathrm{m}$, Whatman) filters, producing filtrates corresponding to the $2.7 \mu \mathrm{m}$ size fraction $(2.7$ $\mathrm{SF})$ and $0.7 \mu \mathrm{m}(0.7 \mathrm{SF})$ size fractions, respectively. Particulate organic carbon and nitrogen of both SF were analyzed on a CN elemental analyzer (Flash 2000 NC Soil Thermo Fisher scientific, Waltham, MA, USA). The difference between 2.7 SF and 0.7 SF will be referred to hereafter as $0.7-2.7$ SF. Preliminary experiments on filtration of Alteromonas sp. showed that $71 \%$ of the cells were recovered in $0.7-2.7 \mathrm{SF}$ and $29 \%$ in $2.7 \mathrm{SF}$. Consequently, 2.7 SF results were considered as estimators of algae cells alone, and 0.7-2.7 SF results as estimators of bacteria and non-living particulate matter.

\section{Dissolved Organic and Inorganic Nitrogen}

Dissolved organic and inorganic nitrogen (DON and DIN, respectively) were estimated daily in the cultures, with a quantification limit of $0.1 \mu \mathrm{M}$. Organic particulate matter (algae and bacteria) was excluded by filtration on GF/F filters $(0.7 \mu \mathrm{m}$, Whatman). The recovered filtrate was then divided into two samples to estimate total dissolved nitrogen and DIN. Dissolved organic nitrogen (DON) was calculated as the difference.

Total dissolved nitrogen was estimated by the wet-oxidation method (Pujo-Pay and Raimbault, 1994), which oxidizes nitrogen of organic compounds into nitrate. DIN and oxidized total dissolved nitrogen samples were stored at $-20^{\circ} \mathrm{C}$ until mineral nitrogen analysis. Ammonium, nitrite, and nitrate in all samples were measured with an autoanalyzer (Autoanalyzer II, Seal Analytical) according to the colorimetric methods of Koroleff (1983) and Solorzano (1969) for ammonium, and Bendschneider and Robinson (1952) for nitrate and nitrite.

\section{Calculations}

Calculations were made at each steady state for the different cultures and for the two dilution rates tested in the experiment. Cell Carbon quota (Algae QC) was calculated as the carbon recovered on GF/D filters divided by the Dunaliella sp. cell concentration. Microalgal C: $\mathrm{N}$ (mol C: mol $\mathrm{N}$ ) ratio was computed as the ratio of particulate carbon to particulate nitrogen on the GF/D filters. Nitrogen partitioning was calculated as the percentage of $\mathrm{N}$ recovered in the different size fractions relative to the $\mathrm{N}$ input with the medium. The rate of $\mathrm{DON}$ release was calculated as DON/Algal carbon $\times$ dilution rate in molN.molC ${ }^{-1} \cdot$ day $^{-1}$. At steady state, $\mathrm{N}$ uptake rate $(\rho$ in molN.molC ${ }^{-1}$. day ${ }^{-1}$ ) in axenic cultures and $\mathrm{N}$ excretion rate ( $\varepsilon$ in molN.molC ${ }^{-1} \cdot$ day $^{-1}$ ) are given by equations 1 and 2 , respectively:

$$
\begin{gathered}
\rho=\frac{D *(N i-N)}{X} \\
\varepsilon=\frac{D * D O N}{X}
\end{gathered}
$$

where $X$ is the carbon algae biomass $\left(\right.$ molC. $\left.\mathrm{L}^{-1}\right), D$ is the dilution rate $\left(\mathrm{day}^{-1}\right), N_{i}$ is ammonium concentration in the input medium (molN.L $\mathrm{L}^{-1}$ ), and $N$ is ammonium concentration in the culture (Burmaster, 1979). At steady state, we consider that $N$ is negligible since it was undetectable.

Nitrogen efficiency can be calculated from Equations (1) and (2), as shown in Equation (3):

$$
E=\frac{\rho-\varepsilon}{\varepsilon}=\frac{N i-D O N}{N i}
$$

Where $E$ varies between 0 and 1 .

\section{RESULTS}

\section{Chemostat}

On the basis of the stability of algal carbon and dilution rate, two steady states of 12 days were defined in the four cultures 
(Figure 1A). The first steady state (SS1) for low dilution rate was reached at day 22 and lasted until day 34 . The increase in dilution rate at day 35 resulted in a decrease in algal carbon (Figure 1A) and algae C: $\mathrm{N}$ ratio (Figure 1D). The second steady state (SS2) was reached at day 41 and lasted until day 53. After day 53, we measured a lower stability of the dilution rate, which was likely due to aging of the tubing of the peristaltic pumps (data not shown). For this reason, measures after day 53 were not taken into account for further analysis. Calculated relative standard deviation of carbon biomass was $<5 \%$ within each steady state for all cultures. As soon as nitrogen was added to the cultures at day 77, a great increase in algal carbon was observed. These results confirmed prior nitrogen limitation in the chemostat.

For each culture, the increase in dilution rate resulted in a decrease in algal carbon concentration in the culture without any significant change in algal nitrogen concentration (Figures 1B,C). Consequently, a decrease in the C: N (mol C: $\mathrm{mol} \mathrm{N}$ ) ratio of algae was observed. Conversely, the increase in dilution rate resulted in a decrease in algal cell biovolume and algal carbon quota per cell (pmolC.cell ${ }^{-1}$ ).

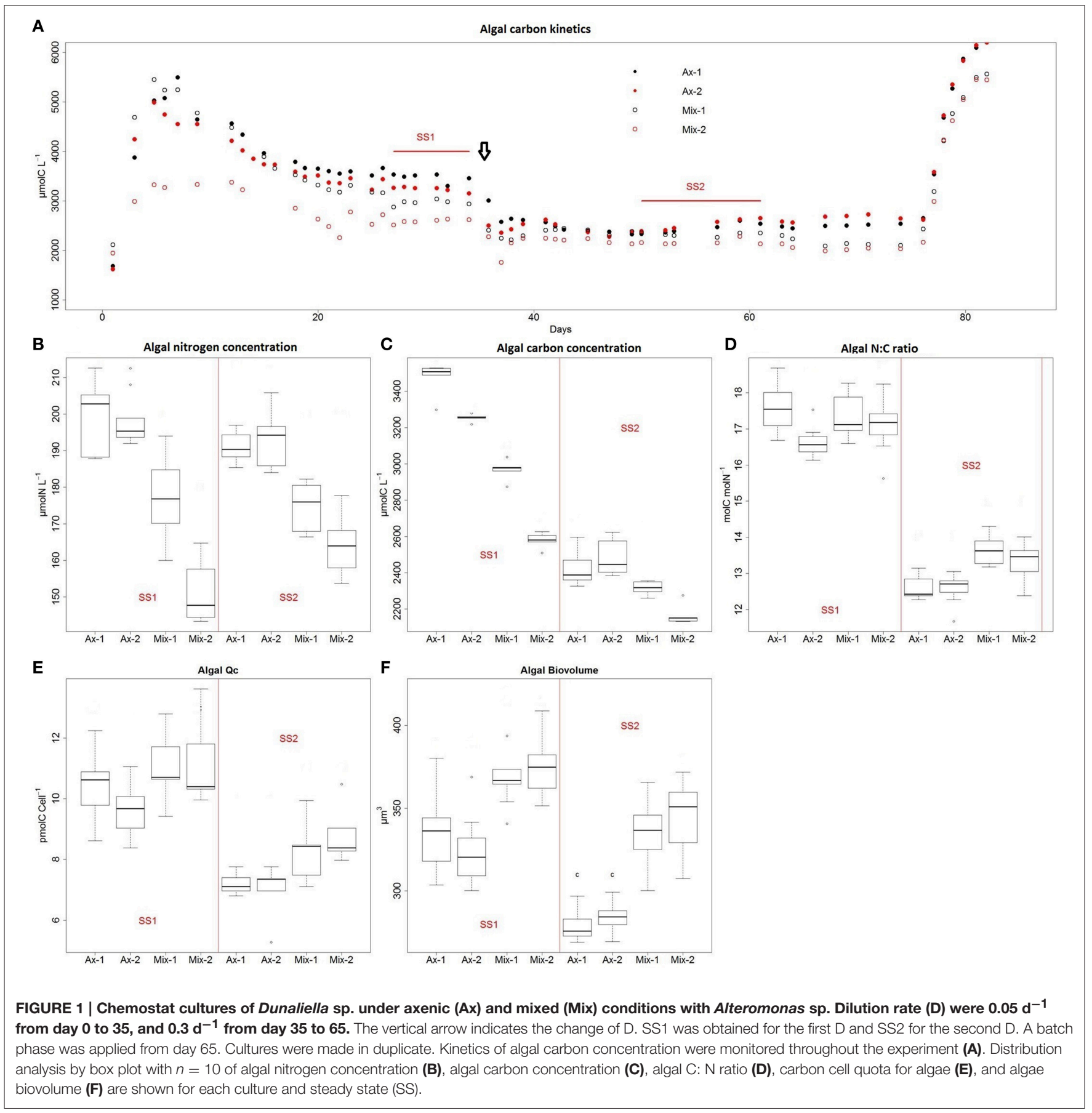




\section{Impact of Bacteria on Algal Physiology}

In SS1, addition of Alteromonas sp. resulted in a $8-26 \%$ decrease in algal carbon concentration and a $9-27 \%$ decrease in algal nitrogen concentration according to the cultures considered (Figures 1B,C). In SS2, an $8-15 \%$ decrease of algal nitrogen concentration was recorded. The impact of the addition of bacteria on algal carbon in SS2 was much lower than in SS1 and was only significant in Mix-2 culture. During the two steady states, Alteromonas sp. addition resulted in a 10-30\% increase in algae biovolume and a $12-20 \%$ increase in algal carbon cell quota (Figures 1E,F).

\section{Bacteria and Extracellular Non-living Particulate Matter}

Axenic algae and bacteria-algae mixtures were cultured for 3 months in chemostats without any external contamination being detected by flow cytometric analysis or microscopic observations. No physical interaction by cell contact between algae and bacteria was observed by microscopy. RAPD analyses of strains isolated in mixed cultures showed $100 \%$ similarity with Alteromonas sp. strain SY007 regardless of which of the two primers was used (RAPD1 or RAPD4), again demonstrating the absence of contamination (data not shown). Flow cytometry analysis recorded $1.2-2.2 \times 10^{6}$ bacteria $\mathrm{ml}^{-1}$ at SS1 and $1.9-4 \times 10^{6}$ bacteria $\mathrm{ml}^{-1}$ at SS2 (Figures 2A,E). This corresponded to 6-10 bacteria per alga at SS1 and 10-20 at SS2.

In axenic cultures, carbon-rich, nitrogen-free particulate matter was detected in the 0.7-2.7 SF (Figures 2B,C). We made the assumption that this organic fraction could be related to nonliving particulate matter released by microalgae during growth. Because nitrogen is absent from this fraction, it is unlikely that its origin was cell death. The particulate organic carbon measured in the $0.7-2.7$ SF of axenic cultures decreased significantly with the increase of dilution rate (Figure 4C).

Biochemical analysis of the 0.7-2.7 SF of mixed cultures revealed a C: $\mathrm{N}$ ratio of $6 \mathrm{~mol} \mathrm{C} / \mathrm{mol} \mathrm{N}$, similar to that of bacteria (Figure 2D). No significant differences in carbon quota between mixed and axenic cultures were recorded in the 0.7-2.7 SF. Therefore, we hypothesized that the $0.7-2.7$ SF of axenic cultures contained mainly non-living particulate, and that the 0.7-2.7 SF of mixed cultures contained mainly bacteria. In mixed culture, the increase in dilution rate induced a decrease in carbon and nitrogen content in the 0.7-2.7 SF, together with an increase in bacterial concentration. This suggested a decrease in the size of bacterial cells when dilution rate increased.

\section{Nitrogen Partitioning}

Because the cultures were grown in nitrogen-limited conditions and because algal nitrogen was decreased by the addition of Alteromonas sp., the partitioning of nitrogen between microalgae, bacteria, dissolved organic matter and dissolved inorganic matter was analyzed in the four chemostats and in both steady states. Under all conditions, dissolved inorganic nitrogen (DIN) remained undetectable. Accordingly, most of the continuouslysupplied ammonium was immediately taken up and used in the growth and metabolism of the organisms present, as expected in nitrogen-limited culture. Figure 3 shows how dissolved organic nitrogen (DON) was the second largest nitrogen compartment after the microalgae compartment in axenic and mixed cultures, and the amount of DON was not impacted by the presence of bacteria.

Increasing dilution rate resulted in: (1) an increase in the proportion of microalgal nitrogen in all cultures with $58-75 \%$ of total nitrogen under SS1 and 74-81\% under SS2; (2) a decrease in the proportion of bacterial nitrogen in mixed cultures with 9-13\% of total nitrogen at SS1 and $4-6 \%$ at SS2; (3) a decrease in the proportion of DON in all cultures with $25-29 \%$ of total nitrogen at SS1 and $18-21 \%$ at SS2 (Figure 3). Calculated data given in Table 1 indicate that the $\mathrm{N}$ limitation imposed resulted in an increase in microalgal $\mathrm{N}$ efficiency.

Furthermore, the addition of bacteria resulted in a decrease in the proportion of microalgal nitrogen from $74-75$ to $58-64 \%$ at SS1 and from $80-81$ to $74-75 \%$ at SS2 (Figure 3). Interestingly, the loss of nitrogen in the algae roughly corresponded to the nitrogen fixed in the bacterial compartment. Our analyses of nitrogen in the different compartments resulted in an almost balanced nitrogen budget.

\section{DISCUSSION}

Relationship between plankton communities are driven by a combination of competition and facilitation that may involve relationships for nitrogen between the different components of bacterioplankton and phytoplankton. On the one hand, during nitrate and ammonium limitation, diazotroph cyanobacteria can fix dinitrogen and consequently may promote the growth of non diazotroph cyanobacteria (Agawin et al., 2007), bacterial communities (Brauer et al., 2015), diatoms and dinoflagellates (Lenes et al., 2001; Mulholland et al., 2006). These interactions may be temperature dependent, and involve facilitation and competition between N2-fixing and non-fixing communities (Brauer et al., 2013, 2015). On the other hand, the relationships for nitrogen include complex promoting and competing interactions for nitrate ammonium and organic nitrogen. These interactions have been of interest for decade (Hutchinson, 1961; Tilman et al., 1982; Bratbak and Thingstad, 1985; Doucette, 1995; Thingstad et al., 1997; Grossart, 1999; Zehr and Ward, 2002) and diatoms-bacteria interactions are subjected to new insights by the use of molecular technical advances (Amin et al., 2015; Bertrand et al., 2015; Diner et al., 2016). The present paper examines the impact of nitrogen limitation on the interactions between heterotrophic bacteria and phytoplankton species by comparing cultures in chemostats and previous batch cultures (Le Chevanton et al., 2013). It underlines interactions for nitrogen and carbon and the role of nutrient limitation on the switch from competition to mutualistic relationships.

Cultures in N-limited chemostat resulted in established equilibrium between bacteria and algae, similar to the observations reported in previous studies under phosphorus limitation (Currie and Kalff, 1984; Bratbak and Thingstad, 1985). At both dilution rates, we obtained steady states that lasted 12 days, offering the possibility to confidently analyze the interactions between bacteria and microalgae in different 


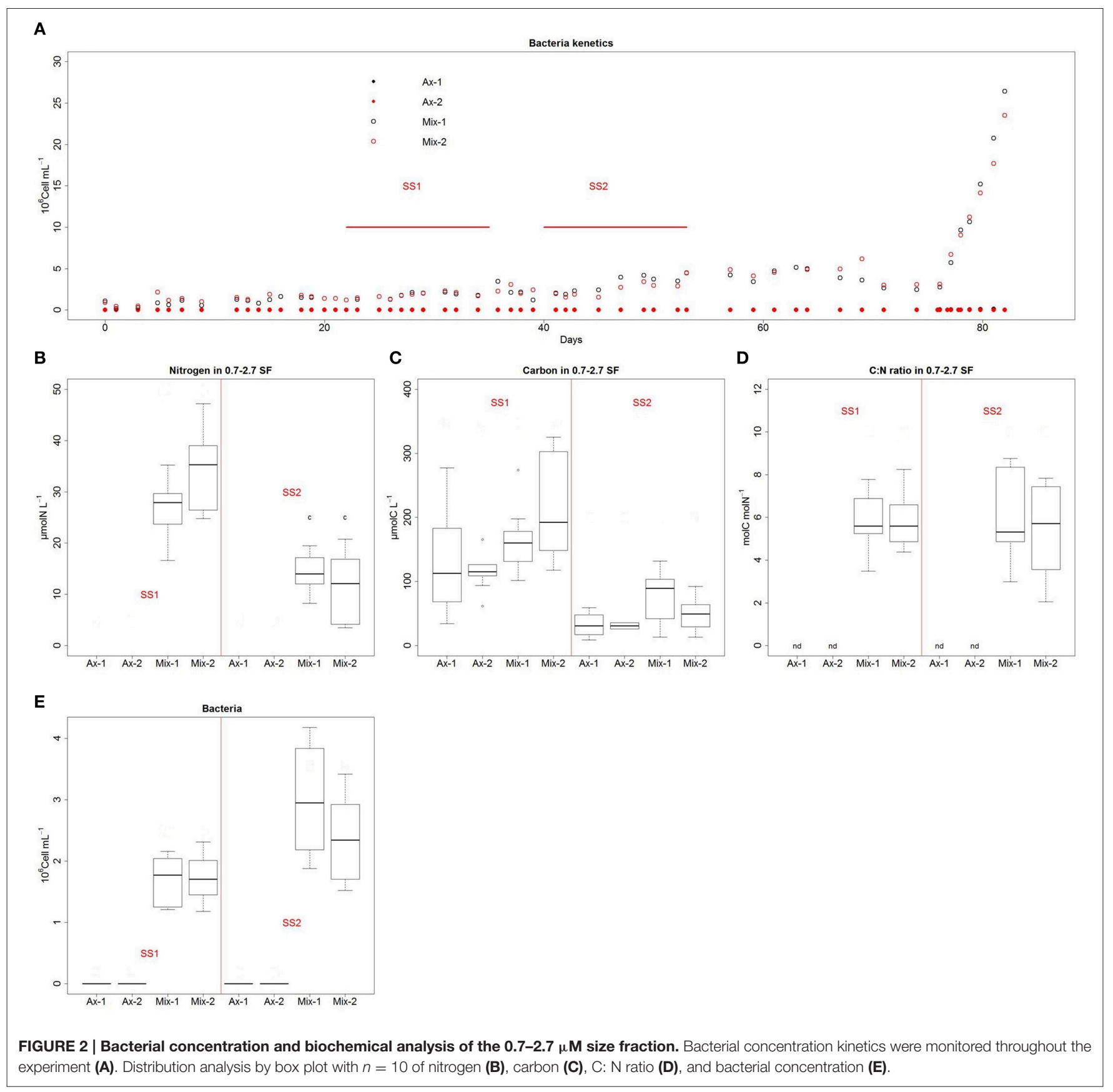

conditions of nitrogen limitation. On the whole, replicates of cultures gave very similar results except for algal nitrogen and carbon in Mix-1 and Mix-2. By checking the total concentration of nitrogen in cultures at steady states (DON + DIN + algal nitrogen + nitrogen in the $0.7-2.7 \mathrm{SF}$ ), it was obvious that total nitrogen in Mix-2 was $20 \mu \mathrm{M}$ lower than in Mix-1. The lower nitrogen input explains the lower steady-state algal carbon and nitrogen in Mix-2, when compared to Mix-1. Nevertheless the two cultures responded similarly to dilution rate variations.

The addition of Alteromonas sp. SY007 strongly increased microalgal cell size- in chemostats, as had been recorded in batch cultures (Le Chevanton et al., 2013). Conversely, a decrease in N limitation resulted in a reduced cell size for microalgae. While similar effects of nitrogen limitation on cell size of unicellular photosynthetic and non-photosynthetic microorganisms have been described in the past (Shuter, 1978), the effect of bacteria on microalgal cell size is less often described. de-Bashan et al. (2002) showed that the addition of the microalgae-growth-promoting bacterium Azospirillum brasilense increased cell size for a strain of the freshwater alga Chlorella vulgaris, but not for another strain of same species or for Chlorella sorokiniana (de-Bashan et al., 2002). Hence, the impact of bacteria on algal cell size 


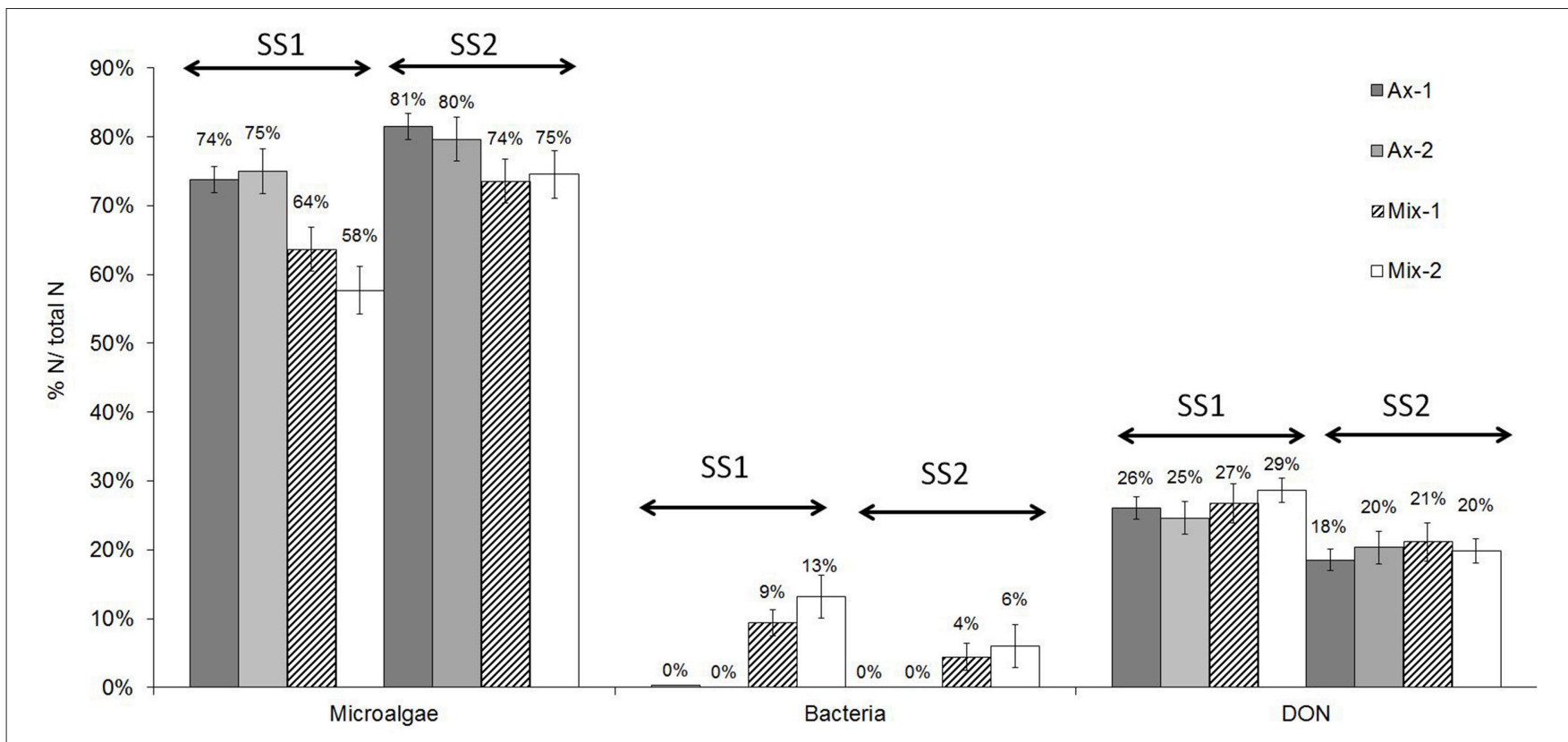

FIGURE 3 | Nitrogen fractioning in axenic and mixed cultures expressed as percentage of the total nitrogen input. Values presented are medians and error bars show standard deviation with $n=5$. DIN remained undetectable.

TABLE 1 | N efficiency (E) in axenic cultures (standard deviation numbers in brackets, $n=8$ ).

\begin{tabular}{lllllll}
\hline & \multicolumn{2}{c}{ SS1 } & & \multicolumn{2}{c}{ SS2 } \\
\cline { 2 - 3 } \cline { 5 - 6 } & Ax1 & Ax2 & & Ax1 & Ax2 \\
\hline$E($ molN: molN) & $0.72(0.02)$ & $0.75(0.02)$ & & $0.82(0.05)$ & $0.83(0.06)$
\end{tabular}

seems to depend on species and strain. The reasons for such morphological adaptation to bacteria remain unclear. It has been suggested that larger surface to volume ratio would increase the competitive advantage by increasing the nutrient input capacity (Kuenen et al., 1977; Smith and Kalff, 1982). The observed decrease in cell size concomitant with the increase in nitrogen limitation is in accordance with this hypothesis. However, the increase in microalgal cell size as a result of bacteria addition seems to be somewhat paradoxical, resulting in less competitive cell physiology when competition for nitrogen increases.

Dissolved organic nitrogen (DON) in chemostats represented $18-30 \%$ of total nitrogen. These amounts are in accordance with previous analysis of DON excretion by phytoplankton species in general (Bronk and Flynn, 2006) and by batch-cultivated Dunaliella tertiolecta in particular (Hulatt and Thomas, 2010). Traditionally, DON has been ignored as a source of nitrogen for phytoplankton, despite evidence that they can use urea directly and free amino-acid via cell-surface and extracellular enzymatic processes (Palenik and Morel, 1990, 1991; Mulholland et al., 2002; Stoecker and Gustafson, 2003). Despite the nitrogenlimited conditions in the chemostats, our results suggest that DON was poorly taken up by Dunaliella sp. Therefore, we hypothesize that ammonium was the major, if not the sole, source of nitrogen for microalgae in this experiment. Moreover, several studies showed that DON excretion and uptake are affected by nitrogen limitation (Tamminen and Irmisch, 1996; Nagao and Miyazaki, 2002). In batch cultures of the green algae Scenedesmus quadricauda and the cyanobacteria Microcystis novacekii and Synechococcus sp., DON was released more readily by nitrogenreplete algae than by nitrogen-limited algae (Bronk, 1999; Nagao and Miyazaki, 2002). Conversely, Newell et al. observed that the production of DON was not affected by nitrogen limitation in chemostats (Newell et al., 1972). In our experiments, DON release was not detected in batch cultures of Dunaliella sp. Focusing on the effect of nitrogen limitation in axenic chemostats on the nitrogen efficiency (Table 1), it becomes obvious that Dunaliella sp. used ammonium-nitrogen more effectively under lower nitrogen limitation.

From mutualism to competition. Batch (Le Chevanton et al., 2013) and continuous cultures (this study) of Dunaliella sp. mixed with Alteromonas sp. SY007 produced apparently contradictory results, i.e., mutualism for nitrogen in batch and competition in chemostat. Since similar growth conditions were applied in the two experiments, we suggest that microbial interactions are mainly driven by nitrogen limitation and initial bacteria: algae ratio. Given that (1) nitrogen resources limit the growth of microalgae, and (2) growth of heterotrophic bacteria depends on organic carbon secretion by microalgae, we propose a schematic picture of the interactions depending on nitrogen input and initial bacteria: algae ratio (Figure 4).

Bacteria use organic carbon excreted by algae. Alteromonas are marine gram-negative heterotrophic proteobacteria (Baumann et al., 1972). Therefore, in continuous and batch cultures without any organic supply, Alteromonas sp. SY007 should have used pre-formed organic matter as a source of energy and 


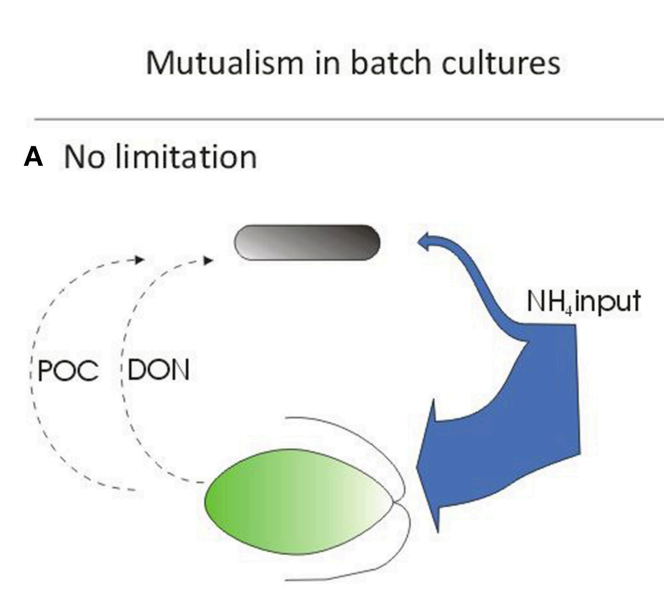

B N starvation

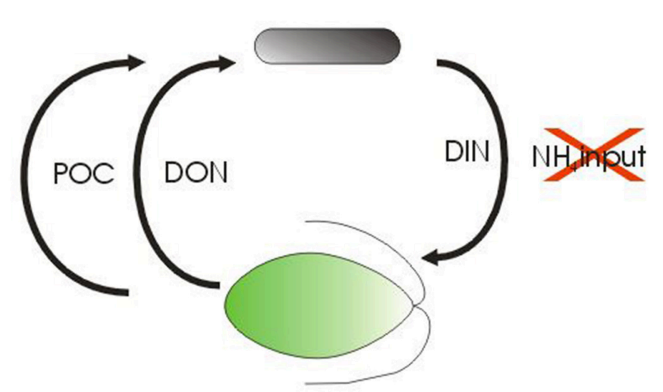

Dunaliellasp.

\section{Competition in chemostats}

\section{Medium $\mathrm{N}$ limitation}

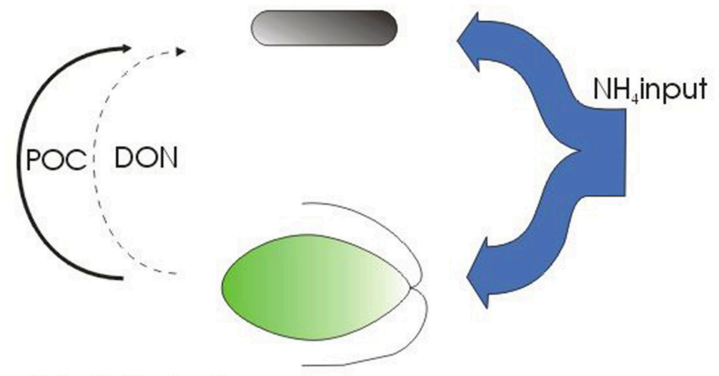

D High $\mathrm{N}$ limitation

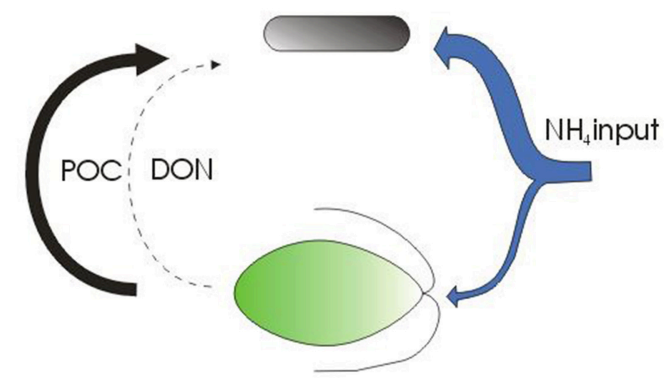

\section{Alteromonas $s p$.}

FIGURE 4 | Schematic presentation of relationships between bacteria and microalgae in batch cultures and chemostat. (A) Start of batch cultures where $\mathrm{NH}_{4}$ provided by the media is high. (B) Nitrogen limitation in batch cultures when $\mathrm{NH}_{4}$ provided by growth media was totally depleted. (C) Chemostat limited in nitrogen at high dilution rate (SS2). Continuous NH4 input is high and nitrogen limitation of algae considered as low. (D) Chemostat limited in nitrogen at low dilution rate (SS1). Continuous NH4 input is lower and nitrogen limitation of algae is high. Arrow size indicates the presumed magnitude of fluxes.

metabolic precursors. Biochemical analyses of the $0.7-2.7 \mathrm{SF}$ suggest that the bacteria consumed organic carbon from nonliving particulate matter. This non-living particulate matter was observed by microscope in the axenic batch and chemostat, and is likely released by microalgae. Unsurprisingly, this confirms that primary production of phytoplankton is a source of carbon and energy for heterotrophic bacterioplankton.

Bacteria use DON and DIN for growth. In our previous study (Le Chevanton et al., 2013), there was strong evidence that $\mathrm{NH}_{4}$ depletion at the end of batch cultures forces bacteria to use DON released by microalgae for their development. Therefore, we suggested that DON was remineralized by bacteria, leading to the observed increase of microalgal nitrogen at the stationary phase in batch culture (Figure 4). In chemostat, ammonium was continuously supplied to both bacteria and algae. Given the absence of direct measurements of bacterial DON uptake and release, it is unclear to what extent this organic substrate supported bacterial growth. However, nitrogen was not observed in the non-living particulate matter of axenic cultures $(0.7-2.7 \mathrm{SF})$. Moreover, DON was not affected by the presence of Alteromonas sp. As a consequence, the use of organic nitrogen released by algae for bacterial growth in chemostats should be questioned. Indeed, our results strongly suggest that bacteria use $\mathrm{NH}_{4}$ rather than DON when $\mathrm{NH}_{4}$ is available. The competitive behavior of bacteria in this study therefore strongly contrasts with the mutualism observed in Le Chevanton et al. (2013). In the chemostat, the decrease of microalgal nitrogen resulting from Alteromonas sp. addition was similar to the amount of nitrogen sequestered in bacteria. Indeed, Baumann et al. (1972) showed that Alteromonas species can use ammonium as their sole nitrogen source. We therefore interpreted our observations as bacteria taking up part of the $\mathrm{NH}_{4}$ in the mixed continuous cultures, leading to competition between bacteria and microalgae for $\mathrm{NH}_{4}$ (Figure 4). Such competition has been previously reported in mesocosms and in cultures of the marine prasinophyte Tetraselmis chui with a bacterial community (Joint et al., 2002; Meseck et al., 2006). Although it is well documented that bacteria collect elements in mineral forms when their needs 
are not fully met by organic matter, (Bratbak and Thingstad, 1985; Joint et al., 2002; Mindl et al., 2005), the reason for the lack of DON consumption by Alteromonas remains unclear. In oceans, bacterioplankton participates in DON consumption by using multiple membrane transporters and extracellular and intracellular hydrolases (Hoppe, 1983; Howarth et al., 1988). On the one hand, it is acknowledged that not all organic matter can be readily metabolized by bacteria, as part of it is refractory. On the other hand, (Barofsky et al., 2009) recorded that diatoms exude different metabolites through the period of bloom development. These authors suggested that most of the compounds exuded are under the control of the physiological state of the algae or the environmental conditions. The apparent paradox observed between batch and chemostat cultures in the present study could therefore have arisen from different DON compounds exuded by microalgae being differentially refractory to bacterial metabolization. Another hypothesis is based on the possibility that enzymatic mechanisms for DON assimilation by bacteria are more energy consuming than direct $\mathrm{NH}_{4}$ assimilation.

One of the outstanding issues in ecology and biodiversity is known as the "paradox of the plankton" (Hutchinson, 1961): How can many species coexist in a seemingly environment limited by a limited number of nutrients when the species compete for these nutrient? Several studies have proposed nonexclusive competition, as reviewed by Wilson (2011). Here, we address a shift between competitive and mutualistic interactions within a simplified community with only two microorganisms. Below we detail two mechanisms that are supported by our results.

Under nitrogen sufficiency, nitrogen competition is driven by the bacteria/algae ratio. In batch cultures, competition for mineral nitrogen only occurred at the beginning of the culture when mineral nitrogen was still available. The batch cultures were inoculated with nitrogen-starved microalgae and an initially low bacteria: algae cell ratio ( $\mathrm{B}: \mathrm{A}=0.3$ ). It is well-known that nitrogen-starved microalgae, with low nitrogen quotas, take up mineral nitrogen rapidly by increasing their cell nitrogen quotas (Droop, 1968). Consequently, in batch cultures, most of the available ammonium was quickly taken up mainly by microalgae. The bacterial population could, therefore, only develop based on DON released by microalgae. The effect of competition from bacteria for DIN would depend on the bacteria: algae ratio and on the absorption rates of algae driven by their physiological nitrogen status. A recent study on interactions in coastal plankton communities showed the role of signaling molecules on the complex exchanges of nitrogen between diatoms and bacteria (Amin et al., 2015) and similar infochemicals could play a role in the Alteromonas sp. - Dunaliella sp. nitrogen interactions.

The results of the present paper indicate that bacteria compete with algae for mineral nitrogen, but nitrogen-limited algae release extracellular particulate organic carbon (POC) that stimulate the growth of the bacterial competitors. The release of POC results from an unbalance between photosynthesis (carbon fixation) and
N uptake (Granum and Myklestad, 2001; Baklouti et al., 2006) and we showed that the release of POC was higher under more severe nitrogen limitation conditions. Paradoxically, microalgae stimulate their competitors for DIN, particularly when they are themselves limited by DIN. Our results are in line with previous studies on interactions between diatoms and marine bacteria under phosphorus limitation (Bratbak and Thingstad, 1985; Mindl et al., 2005). The authors suggested that "algae stressed by lack of mineral nutrients respond in a manner whereby they stimulate their competitors for the lacking nutrients" (Bratbak and Thingstad, 1985). Our study gives insight on the underlying mechanisms in nitrogen limitation. Recent studies on interactions between phytoplankton communities dominated by diatoms and bacterial populations at the costal Antartic sea ice edge have underlined a variety of interactions such as mutualistic relationships for organic carbon, competition for iron and mutualistic or competition for cobalamin that is produced by only certain groups of bacteria (Bertrand et al., 2015). Our studies are in line with these observations of complex relationships and give insight on the importance of nutrient limitation on nature of interactions.

As a conclusion, we have shown that microalgae and heterotrophic bacteria coexist in cultures at a stable equilibrium thanks to complex win-win relationships. These interactions are the results of (1) the need of bacteria to take up carbon released by microalgae and (2) a complex relationship for nitrogen that can shift from competitive to mutualistic relationship, this driven by mineral nitrogen availability. These results participate to the growing field of research on the relationships inside planktonic communities that drive marine primary productivity.

\section{AUTHOR CONTRIBUTIONS}

ML, MG, JC, and GB participated to the conception of the work in the whole. ML, MG, EL, NS, and GB contributed to the experiments and analysis of data. ML, MG, BS, and GB contributed to the interpretation of the data and to the redaction of the paper.

\section{ACKNOWLEDGMENTS}

This publication presents results supported by the ANR BIOE 2008 Symbiose project. Thanks to the IFREMER LER/MPL laboratory for technical support for elemental $\mathrm{CN}$ and ionchromatography analysis. We also thank the anonymous reviewers for their critical comments that greatly improves the manuscript and Helen McCombie for editing the English of the manuscript.

\section{SUPPLEMENTARY MATERIAL}

The Supplementary Material for this article can be found online at: http://journal.frontiersin.org/article/10.3389/fmars. 2016.00123 


\section{REFERENCES}

Agawin, N. S. R., Rabouille, S., Veldhuis, M. J. W., Servatius, L., Hol, S., van Overzee, H. M. J., et al. (2007). Competition and facilitation between unicellular nitrogen-fixing cyanobacteria and non-nitrogen-fixing phytoplankton species. Limnol. Oceanogr. 52, 2233-2248. doi: 10.4319/lo.2007.52.5.2233

Amin, S. A., Hmelo, L. R., van Tol, H. M., Durham, B. P., Carlson, L. T., Heal, K. R., et al. (2015). Interaction and signalling between a cosmopolitan phytoplankton and associated bacteria. Nature 522, 98-101. doi: 10.1038/nature14488

Azam, F., Fenchel, T., Field, J., Gray, J., Meyer-Reil, L., and Thingstad, F. (1983). The ecological role of water-column microbes in the sea. Mar. Ecol. Prog. Ser. 10, 257-263. doi: 10.3354/meps010257

Baklouti, M., Diaz, F., Pinazo, C., Faure, V., and Quéguiner, B. (2006). Investigation of mechanistic formulations depicting phytoplankton dynamics for models of marine pelagic ecosystems and description of a new model. Prog. Oceanogr. 71, 1-33. doi: 10.1016/j.pocean.2006.05.002

Barofsky, A., Vidoudez, C., and Pohnert, G. (2009). Metabolic profiling reveals growth stage variability in diatom exudates. Limnol. Oceanogr. Methods 7, 382-390. doi: 10.4319/lom.2009.7.382

Barzegari, A., Hejazi, M. A., Hosseinzadeh, N., Eslami, S., Aghdam, E. M., and Hejazi, M. S. (2009). Dunaliella as an attractive candidate for molecular farming. Mol. Biol. Rep. 37, 3427-3430. doi: 10.1007/s11033-009-9933-4

Baumann, L., Baumann, P., Mandel, M., and Allen, R. D. (1972). Taxonomy of aerobic marine Eubacteria. J. Bacteriol. 110, 402 -429.

Bendschneider, K., and Robinson, R. J. (1952). A new spectrophotometric determination of nitrite in sea water. J. Mar. Res. 11, 87-96.

Bertrand, E. M., McCrow, J. P., Moustafa, A., Zheng, H., McQuaid, J. B., Delmont, T. O., et al. (2015). Phytoplankton-bacterial interactions mediate micronutrient colimitation at the coastal Antarctic sea ice edge. Proc. Natl. Acad. Sci. U.S.A. 112, 9938-9943. doi: 10.1073/pnas.1501615112

Bratbak, G., and Thingstad, T. (1985). Phytoplankton-bacteria interactions - an apparent paradox - analysis of a model system with both competition and commensalism. Mar. Ecol. Prog. Ser. 25, 23-30. doi: 10.3354/meps025023

Brauer, V. S., Stomp, M., Bouvier, T., Fouilland, E., Leboulanger, C., ConfuriusGuns, V., et al. (2015). Competition and facilitation between the marine nitrogen-fixing cyanobacterium Cyanothece and its associated bacterial community. Front. Microbiol. 5:795. doi: 10.3389/fmicb.2014.00795

Brauer, V. S., Stomp, M., Rosso, C., van Beusekom, S. A., Emmerich, B., Stal, L. J., et al. (2013). Low temperature delays timing and enhances the cost of nitrogen fixation in the unicellular cyanobacterium Cyanothece. ISME J. 7, 2105-2115. doi: 10.1038 /ismej.2013.103

Bronk, D. (1999). Rates of NH4+ uptake, intracellular transformation and dissolved organic nitrogen release in two clones of marine Synechococcus spp. J. Plankton Res. 21, 1337-1353. doi: 10.1093/plankt/21.7.1337

Bronk, D. A., and Flynn, K. J. (2006). "Algal cultures as a tool to study the cycling of dissolved organic Nitrogen," in Algal Cultures, Analogues of Blooms and Applications, ed S. R. V. Durvasula (New Delhi: Oxford \& IBH Publishing), 301-341.

Burmaster, D. E. (1979). The continuous culture of phytoplankton: mathematical equivalence among three steady-state models. Am. Nat. 113, 123-134. doi: $10.1086 / 283368$

Capblancq, J. (1990). Nutrient dynamics and pelagic food web interactions in oligotrophic and eutrophic environments - an overview. Hydrobiologia 207, 1-14. doi: 10.1007/BF00041435

Capone, D. G. (2000). "The marine nitrogen cycle," in Microbial Ecology of the Oceans, ed D. L. Kirchman (New York, NY: Wiley), 455-494.

Charrier, A., Bérard, J.-B., Bougaran, G., Carrier, G., Lukomska, E., Schreiber, N., et al. (2015). High-affinity nitrate/nitrite transporter genes (Nrt2) in Tisochrysis lutea: identification and expression analyses reveal some interesting specificities of Haptophyta microalgae. Physiol. Plant. 154, 572-590. doi:10.1111/ppl.12330

Cole, J. J. (1982). Interactions between bacteria and algae in aquatic ecosystem. Annu. Rev. Ecol. Syst. 13, 291-314. doi: 10.1146/annurev.es.13.110182.001451

Croft, M. T., Lawrence, A. D., Raux-Deery, E., Warren, M. J., and Smith, A. G. (2005). Algae acquire vitamin B12 through a symbiotic relationship with bacteria. Nature 438, 90-93. doi: 10.1038/nature04056

Currie, D. J., and Kalff, J. (1984). Can bacteria outcompete phytoplankton for phosphorus? A chemostat test. Microb. Ecol. 10, 205-216. doi: 10.1007/BF02010935
de-Bashan, L. E., Bashan, Y., Moreno, M., Lebsky, V. K., and Bustillos, J. J. (2002). Increased pigment and lipid content, lipid variety, and cell and population size of the microalgae Chlorella spp. when co-immobilized in alginate beads with the microalgae-growth-promoting bacterium Azospirillum brasilense. Can. J. Microbiol. 48, 514-521. doi: 10.1139/w02-051

Diner, R. E., Schwenck, S. M., McCrow, J. P., Zheng, H., and Allen, A. E. (2016). Genetic manipulation of competition for nitrate between heterotrophic bacteria and diatoms. Aquat. Microbiol. 7:880. doi: 10.3389/fmicb.2016.00880

Doucette, G. J. (1995). Interactions between bacteria and harmful algae: a review. Nat. Toxins 3, 65-74. doi: 10.1002/nt.2620030202

Droop (1968). Vitamin B12 and marine ecology IV. The kinetics of uptake, growth and inhibition in monochrysis lutheri. J. Marine Biol. Assoc. U.K. 48, 689-733. doi: 10.1017/S0025315400019238

Falkowski, P. G., Barber, R. T., and Smetacek, V. (1998). Biogeochemical controls and feedbacks on ocean primary production. Science 281, 200-206. doi: 10.1126/science.281.5374.200

Falkowski, P. G., Fenchel, T., and Delong, E. F. (2008). The microbial engines that drive Earth's biogeochemical cycles. Science 320, 1034-1039. doi: $10.1126 /$ science. 1153213

Granum, E., and Myklestad, S. M. (2001). Mobilization of $\beta-1,3$-glucan and biosynthesis of amino acids induced by $\mathrm{NH} 4+$ addition to N-limited cells of the marine diatom Skeletonema costatum (Bacillariophyceae). J. Phycol. 37, 772-782. doi: 10.1046/j.1529-8817.2001.01005.x

Grossart, H. (1999). Interactions between marine bacteria and axenic diatoms (Cylindrotheca fusiformis, Nitzschia laevis, and Thalassiosira weissflogii) incubated under various conditions in the lab. Aquat. Microb. Ecol. 19, 1-11. doi: 10.3354/ame019001

Hoppe, H.-G. (1983). Significance of exoenzymatic activities in the ecology of brackish water: measurements by means of methylumbelliferyl-substrates. Mar. Ecol. Prog. Ser. 11, 299-308. doi: 10.3354/meps011299

Hosseini Tafreshi, A., and Shariati, M. (2009). Dunaliella biotechnology: methods and applications. J. Appl. Microbiol. 107, 14-35. doi: 10.1111/j.13652672.2009.04153.x

Howarth, R. W., Marino, R., and Cole, J. J. (1988). Nitrogen fixation in freshwater, estuarine, and marine ecosystems. 2. Biogeochemical controls. Limnol. Oceanogr. 33, 688-701. doi: 10.4319/lo.1988.33.4part2.0688

Hulatt, C. J., and Thomas, D. N. (2010). Dissolved organic matter (DOM) in microalgal photobioreactors: a potential loss in solar energy conversion? Bioresour. Technol. 101, 8690-8697. doi: 10.1016/j.biortech.2010.06.086

Hutchinson, G. E. (1961). The paradox of the plankton. Am. Nat. 95, 137-145. doi: $10.1086 / 282171$

Joint, I., Henriksen, P., Fonnes, G. A., Bourne, D., Thingstad, T. F., and Riemann, B. (2002). Competition for inorganic nutrients between phytoplankton and bacterioplankton in nutrient manipulated mesocosms. Aquat. Microb. Ecol. 29, 145-159. doi: 10.3354/ame029145

Kirchman, D. L. (1994). The uptake of inorganic nutrients by heterotrophic bacteria. Microb. Ecol. 28, 255-271. doi: 10.1007/BF00166816

Kirchman, D. L., and Wheeler, P. A. (1998). Uptake of ammonium and nitrate by heterotrophic bacteria and phytoplankton in the sub-Arctic Pacific. Deep Sea Res. Part Oceanogr. Res. Pap. 45, 347-365. doi: 10.1016/S0967-0637(97)00075-7

Koroleff, F. (1983). "Determination of ammonia," in Methods of Seawater Analysis, eds K. Grasshoff, M. Ehrhardt, and K. Kremllng (Weinheim: Verlag Chemie), 150-157.

Kuenen, J. G., Boonstra, J., Schröder, H. G., and Veldkamp, H. (1977). Competition for inorganic substrates among chemoorganotrophic and chemolithotrophic bacteria. Microb. Ecol. 3, 119-130. doi: 10.1007/BF02010401

Le Chevanton, M., Garnier, M., Bougaran, G., Schreiber, N., Lukomska, E., Bérard, J.-B., et al. (2013). Screening and selection of growth-promoting bacteria for Dunaliella cultures. Algal Res. 2, 212-222. doi: 10.1016/j.algal.2013.05.003

Lenes, J. M., Darrow, B. P., Cattrall, C., Heil, C. A., Callahan, M., Vargo, G. A., et al. (2001). Iron fertilization and the Trichodesmium response on the West Florida shelf. Limnol. Oceanogr. 46, 1261-1277. doi: 10.4319/lo.2001.46.6.1261

Lipschultz, F. (1995). Nitrogen-specific uptake rates of marine-phytoplankton isolated from natural-populations of particles by flow-cytometry. Mar. Ecol. Prog. Ser. 123, 245-258. doi: 10.3354/meps123245

Mata, T. M., Martins, A. A., and Caetano, N. S. (2010). Microalgae for biodiesel production and other applications: a review. Renew. Sustain. Energy Rev. 14, 217-232. doi: 10.1016/j.rser.2009.07.020 
Meseck, S. L., Smith, B. C., Wikfors, G. H., Alix, J. H., and Kapareiko, D. (2006). Nutrient interactions between phytoplankton and bacterioplankton under different carbon dioxide regimes. J. Appl. Phycol. 19, 229-237. doi: 10.1007/s10811-006-9128-5

Mindl, B., Sonntag, B., Pernthaler, J., Vrba, J., and Posch, R. P. (2005). Effects of phosphorus loading on interactions of algae and bacteria: reinvestigation of the "phytoplankton- bacteria paradox" in a continuous cultivation system. Aquat. Microb. Ecol. 38, 203-213. doi: 10.3354/ame038203

Moore, C. M., Mills, M. M., Arrigo, K. R., Berman-Frank, I., Bopp, L., Boyd, P. W., et al. (2013). Processes and patterns of oceanic nutrient limitation. Nat. Geosci. 6, 701-710. doi: 10.1038/ngeo1765

Mulholland, M. R., Bernhardt, P. W., Heil, C. A., Bronk, D. A., and O'Neil, J. M. (2006). Nitrogen fixation and release of fixed nitrogen by Trichodesmium spp. in the Gulf of Mexico. Limnol. Oceanogr. 51, 1762-1776. doi: 10.4319/lo.2006.51.4.1762

Mulholland, M. R., Gobler, C. J., and Lee, C. (2002). Peptide hydrolysis, amino acid oxidation, and nitrogen uptake in communities seasonally dominated by Aureococcus anophagefferens. Limnol. Oceanogr. 47, 1094-1108. doi: 10.4319/lo.2002.47.4.1094

Nagao, F., and Miyazaki, T. (2002). Release of dissolved organic nitrogen from Scenedesmus quadricauda (Chlorophyta) and Microcystis novacekii (Cyanobacteria). Aquat. Microb. Ecol. 27, 275-284. doi: 10.3354/ame027275

Natrah, F. M. I., Bossier, P., Sorgeloos, P., Yusoff, F. M., and Defoirdt, T. (2014). Significance of microalgal-bacterial interactions for aquaculture. Rev. Aquac. 6, 48-61. doi: 10.1111/raq.12024

Newell, B. S., Dalpont, G., and Grant, B. R. (1972). The excretion of organic nitrogen by marine algae in batch and continuous culture. Can. J. Bot. 50, 2605-2611. doi: 10.1139/b72-334

Palenik, B., and Morel, F. (1990). Comparison of cell-surface l-amino-acid oxidases from several marine-phytoplankton. Mar. Ecol. Prog. Ser. 59, 195-201. doi: 10.3354/meps059195

Palenik, B., and Morel, F. (1991). Amine oxidases of marine-phytoplankton. Appl. Environ. Microbiol. 57, 2440-2443.

Park, J., Jin, H.-F., Lim, B.-R., Park, K.-Y., and Lee, K. (2010). Ammonia removal from anaerobic digestion effluent of livestock waste using green alga Scenedesmus sp. Bioresour. Technol. 101, 8649-8657. doi: 10.1016/j.biortech.2010.06.142

Park, Y., Je, K.-W., Lee, K., Jung, S.-E., and Choi, T.-J. (2008). Growth promotion of Chlorella ellipsoidea by co-inoculation with Brevundimonas sp. isolated from the microalga. Hydrobiologia 598, 219-228. doi: 10.1007/s10750-007-9152-8

Pujo-Pay, M., and Raimbault, P. (1994). Improvement of the wet-oxidation procedure for simultaneous determination of particulate organic nitrogen and phosphorus collected on filters. Mar. Ecol. Prog. Ser. 105, 203-207. doi: 10.3354/meps105203

Shuter, B. J. (1978). Size dependence of phosphorus and nitrogen subsistence quotas in unicellular microorganisms. Limnol. Oceanogr. 23, 1248-1255. doi: 10.4319/lo.1978.23.6.1248

Smith, R. E. H., and Kalff, J. (1982). Size-dependent phosphorus uptake kinetics and cell quota in phytoplankton1. J. Phycol. 18, 275-284. doi: 10.1111/j.15298817.1982.tb03184.x
Solorzano, L. (1969). Determination of ammonia in natural sea waters by the phenol-hypochlorite method. Am. Soc. Limnol. Oceanogr. 14, 799-801. doi: 10.4319/lo.1969.14.5.0799

Spolaore, P., Joannis-Cassan, C., Duran, E., and Isambert, A. (2006). Commercial applications of microalgae. J. Biosci. Bioeng. 101, 87-96. doi: 10.1263/jbb.101.87

Stoecker, D., and Gustafson, D. (2003). Cell-surface proteolytic activity of photosynthetic dinoflagellates. Aquat. Microb. Ecol. 30, 175-183. doi: 10.3354/ame030175

Strom, S. L. (2008). Microbial ecology of ocean biogeochemistry: a community perspective. Science 320, 1043-1045. doi: 10.1126/science.1153527

Tai, V., Paulsen, I. T., Phillippy, K., Johnson, D. A., and Palenik, B. (2009). Wholegenome microarray analyses of Synechococcus-Vibrio interactions. Environ. Microbiol. 11, 2698-2709. doi: 10.1111/j.1462-2920.2009.01997.x

Tamminen, T., and Irmisch, A. (1996). Urea uptake kinetics of a midsummer planktonic community on the SW coast of Finland. Mar. Ecol. Prog. Ser. 130, 201-211. doi: 10.3354/meps130201

Tilman, D, Kilham, S S, and Kilham, P. (1982). Phytoplankton community ecology: the role of limiting nutrients. Annu. Rev. Ecol. Syst. 13, 349-372. doi: 10.1146/annurev.es.13.110182.002025

Thingstad, T. F., Hagstrom, A., and Rassoulzadegan, F. (1997). Accumulation of degradable DOC in surface waters: is it caused by a malfunctioning microbial loop? Limnol. Oceanogr. 42, 398-404. doi: 10.4319/lo.1997.42. 2.0398

Vasseur, C., Bougaran, G., Garnier, M., Hamelin, J., Leboulanger, C., Le Chevanton, M., et al. (2012). Carbon conversion efficiency and population dynamics of a marine algae-bacteria consortium growing on simplified synthetic digestate: first step in a bioprocess coupling algal production and anaerobic digestion. Bioresour. Technol. 119, 79-87. doi: 10.1016/j.biortech.2012. 05.128

Walne, P. R. (1970). Studies On The Food Value of Nineteen Genera Of Algae To Juvenile Bivalves of The Genera Ostrea, Crassostrea, Mercenaria and Mytilus. Fishery investigations Series II, Vol. 26. London: Ministry of Agriculture.

Wilson, J. B. (2011). The twelve theories of co-existence in plant communities: the doubtful, the important and the unexplored. J. Veg. Sci. 22, 184-195. doi: 10.1111/j.1654-1103.2010.01226.x

Zehr, J. P., and Ward, B. B. (2002). Nitrogen cycling in the ocean: new perspectives on processes and paradigms. Appl. Environ. Microbiol. 68, 1015-1024. doi: 10.1128/AEM.68.3.1015-1024.2002

Conflict of Interest Statement: The authors declare that the research was conducted in the absence of any commercial or financial relationships that could be construed as a potential conflict of interest.

Copyright (c) 2016 Le Chevanton, Garnier, Lukomska, Schreiber, Cadoret, SaintJean and Bougaran. This is an open-access article distributed under the terms of the Creative Commons Attribution License (CC BY). The use, distribution or reproduction in other forums is permitted, provided the original author(s) or licensor are credited and that the original publication in this journal is cited, in accordance with accepted academic practice. No use, distribution or reproduction is permitted which does not comply with these terms. 